\title{
Sct. Marie kirke i Sønderborg - portræet af en 400-årigs historie
}

\author{
af GUNTER WEITLING
}

I efteråret 2000 fejrede Sct. Marie kirke i Sønderborg 400 års jubilæum. I den anledning belyser dr.theol. Günter Weitling, Padborg, tidligere sognepræst for den tyske del af menighederne i Sønderborg, her kirkens historie. Sct. Marie kirke havde på nogle punkter en historie meget forskellig fra andre kirker i Sonderjylland - og dog afspejler beretningen almene træk i sønderjysk kirkehistorie gennem mere end $400 \mathrm{ar}^{1}{ }^{1}$

\section{Middelalderens uafklarede forhold}

For godt 1000 år siden blev Danmark kristnet. 600 år senere fik renæssancen og reformationen deres gennembrud, også i Sønderborg, og først på dette tidspunkt trådte det kirkelige liv fuldt og helt ud af sin anonymitet samtidig med, at Sct. Marie kirke blev bygget. $1 \frac{1}{2}$ gange så lang tid som de 400 år, der er gået, siden kirken blev indviet i 1500tallets sidste år, har kristendommen været kendt blandt menneskene på øen Als.

Langt op i tiden var Sønderborg kirke anneks til Ulkebøl og udgjorde en del af dette sogn. I 1523 synes det endnu at have været tilfældet. I 1541 omtales Sønderborg dog ikke mere som anneks til Ulkebøl. En ændring af forholdene er sandsynligvis indtrådt i tidsrummet fra 1523-1541.

Sønderborgs middelalderlige kirker er som byen i sin helhed vokset op i skyggen af Sønderborg slot. I modsætning til slottets hiștorie foreligger der dog ikke mange skriftligt dokumenterede oplysninger om kirkerne. Middelalderens persongalleri er bortset fra store herskeres og kendte kirkefolks liv anonymt. Også kirke- og menighedslivet i Sønderborg træder forst ud af anonymiteten, samtidig med at Sct. Marie kirke blev bygget. I renæssance- og reformationstiden bliver kirkebygningens historie kirkehistorie i den forstand, at bygningen forbindes med mennesker, hvis identitet synliggøres i et stadigt 
større omfang. Kirken og menigheden træder ind i historien og efterlader sig spor.

Indtil da er præsterne blot navne. Ældst er Arnold Bentzen eller Arnoldus de Bentzin, som omtales i midten af 14 . århundrede. Godt 100 år senere nævnes Wilhelm Hermansen, der fik sin udnævnelse den 4. november 1458. Kendt er også Johannes von Alckendorp, hvis virke vil blive omtalt nedenfor. Peter Ankersen overtog sit embede $\mathbf{i}$ 1517, efter at Johan Grote måtte opgive det på kongens og hertugens foranledning. Ankersen var tillige domherre ved kollegiatkapitlet i Haderslev og sognepræst i Fjelstrup, til hvilket sogn Ulkebøl og Sønderborg var annekser. Peter Ankersen havde studeret i Rostock og Bologna og blev formodentlig afskediget fra embedet i Fjelstrup, fordi Thomas Petersen (Petri) fra Slesvig havde formået at skaffe sig et paveligt ventebrev på embederne i Fjelstrup og Sønderborg. Ankersen førte en årelang proces for kurien i Rom, og opgav først sagen $i$ 1523 - tre år efter, at Thomas Petersen havde tiltrådt embederne.

Også Petersen blev et offer for de kaotiske kirkelige forhold og pavernes stadige indblanding $i$ embedsbesættelserne. Henricus Brandis (Brandt) fik således den 4 . november 1520 pavens løfte på, at han kunne overtage de to embeder. Han stammede fra Bremen og havde været vikar ved Sct. Peter Paul alteret i Sct. Nikolai kirke i Flensborg. Han havde endvidere beklædt et embede som arkivar ved kurien $i$ Rom. Ej heller Brandis formåede dog at hævde sig i praksis.

Pave Hadrian VI (1522-1523), den sidste ikke-italienske pave og en asketisk, virkelighedsfjern personlighed med en fortid som inkvisitor i Spanien, gav i et brev dateret den 25 . august 1523 den kun 18-årige klerk Henrik Holck provisio på kirkerne i Ulkebøl og Sønderborg på den betingelse, at han lod sig ordinere inden syv år. ${ }^{2}$ Den pavelige provision, d.v.s. den lovformelige besættelse af et ledigt embede, har i det foreliggende tilfælde formodentlig kun omfattet det første led, der var udpegelsen af kandidaten. Om de følgende led - stadfæstelsen af embedets overdragelse og indsættelsen $i$ embedet - i Henrik Holcks tilfælde nogensinde har fundet sted, turde være mere end tvivlsomt. ${ }^{3}$ I 1528, på et tidspunkt, hvor det lutherske røre var ved at opbygge nye kirkelige strukturer, var Henrik Holck immatrikuleret i Wittenberg. Her blev han uden tvivl påvirket af de nye tanker og Luthers kontroverser med Zwingli og dennes ligesindede, der kulminerede i netop dette år. Den til nomineringen knyttede betingelse har han tilsyneladende ikke overholdt. I 1536 var han degn i Bergen og 


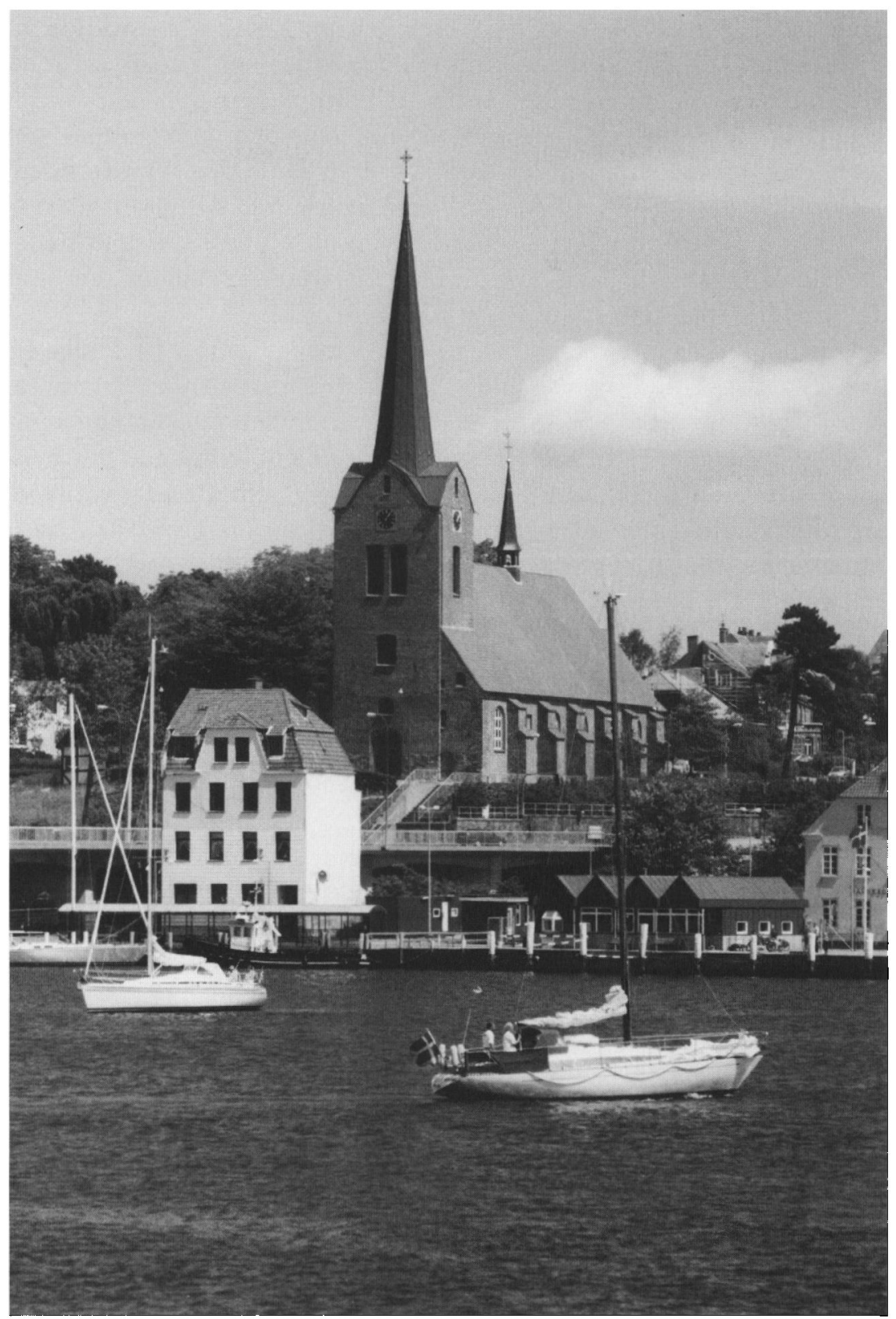

Sct. Marie kirke, Sønderborg i jubilæumsåret. Foto P.W. Weber, Sønderborg. 
sættes i 1538 i forbindelse med Hellig Kors kapellet i Roskilde. ${ }^{4}$ I 1546 fulgte han ikke længere kravet om cølibat, men giftede sig med Magdalene Andersdatter Reventlow til Søbo på Fyn.

Henrik Holck hører til en kendt alsisk adelsslægt og blev opdraget på herregården Rønhave, der sammen med Ballegård og yderligere jorder i Ulkebøl ejedes af hans far Bertel Holck. Ved dennes død arvede sønnen Henrik Rønhave og kom siden også i besiddelse af Ballegård samt vidstrakte jorder, i 1573 bl.a. fem gårde i Ulkebøl, der havde tilhørt hertug Hans den Ældre i Haderslev. ${ }^{5}$

Ulkebøl kirkes prædikestol blev i 1547 skænket af Henrik Holck og hustru og også den fremragende fløj-altertavle fremstillet i Antwerpen $i$ begyndelsen af 1500 -tallet samt andre inventargenstande siges at være doneret af Henrik Holck. Det giver dog anledning til eftertanke, at netop en mand, der stod reformatoren Luther nær, skal have skænket et alter med bl.a. fremstillinger af den H. Franz af Assisi. Muligheden for, at Henrik Holck har siddet inde med sognepræsteembedet i Ulkebøl indtil sin død i 1579, forekommer ikke særlig stor. I en årrække virkede han som sekretær ved Frederik Is og Christian IIIs kancelli. Nogle af hans sønner og nærmeste slægtninge beklædte høje positioner i samfundet. Den yngste af Christian Holcks sønner var rigsråd under Christian IV. Ditlev Holck, den tredieældste af fire sønner, var først lensmand på København slot og derefter på Kronborg.

Selvom der foreligger en del oplysninger om Henrik Holck, er hans biografi dog behæftet med en del uafklarede spørgsmål. Det er bl.a. vanskeligt at se hvordan han har kunnet koordinere udøvelsen af de nævnte embeder. Hans holdning til det lutherske røre under studieopholdet i Wittenberg og vejen til antagelse af den nye lære foreligger der ingen nærmere oplysninger om. Fremtrædende medlemmer af den indflydelsesrige slægt skal have sympatiseret med den katolske reaktion. Det turde dog være utænkeligt, at Henrik Holck har kunnet udføre hvervet som kancellisekretær under Christian III uden at have været lutheraner.

Det er yderst vanskeligt at gøre rede for middelalderens præsteembeder. Nederst $\mathrm{i}$ hierarkiet stod de jævne præster i den lavere gejstlighed, over dem stod sognepræsten. Sidstnævnte stilling var også attraktiv for medlemmer af ansete adelsfamilier. Dette gjaldt bl.a. embederne på landet, efter at det $\mathrm{i}$ løbet af middelalderen var blevet muligt at lægge den egentlige udøvelse af præstetjenesten $\mathrm{i}$ hænderne på 
en fast ansat personlig vikar. Det var ikke usædvanligt, at en højere rangerende gejstlig lod samtlige gudstjenester forrette af stedfortrædere. Domherren Peter Ankersen har givetvis ladet sig repræsentere af vikarer. På denne måde har han været $\mathrm{i}$ stand til at beklæde flere også mindre embeder på landet.

Til gruppen af »evige vikarer« der beklædte faste embeder knyttet til bestemte altre og formaliserede stiftelser, må Johannes von Alckendorp regnes. Disse »evige vikarer « kaldtes capellanei, hvis de havde til opgave at betjene et kapel eller et betydeligt alter tilknyttet et sådant. Købstadskirker gik i øvrigt ofte under betegnelsen "kapeller", fordi de var grundlagt senere end de landsbykirker, hvortil de oprindelig hørte.

\section{Sct. Nikolai kirke}

Sønderborgs ældste bykirke var indviet til Sct. Nikolai. Som det var normalt i middelalderen, var der knyttet flere præster til en bykirke. De var ofte forbundet i et præstegilde, et såkaldt kaland. I Sønderborg var præstegildet viet til Vor Frue. Præsten Johan Grote fra Bremen, der bl.a. medvirkede ved udstedelsen og oversættelsen af byens latinske skomagerskrå til nedertysk, og de allerede omtalte præster var kirkens sognepræster hhv. designerede sognepræster eller vikarer. Som allerede antydet har de dog i de sjældneste tilfælde varetaget deres embede personligt. Altertjenesten blev forrettet af vikarer, medens sognepræsterne selv nød deres indtægter andetsteds. Sct. Nikolai kirke havde flere sidealtre og dermed flere vikarer. Der var altre for apostlene Sct. Peter og Sct. Povl, to helgener der efter middelalderens opfattelse var de vigtigste i apostelskaren, selvom Paulus i Bibelen ikke henregnes til »de tolv«. Peter repræsenterede med sit attribut nøglen den kirkelige magt, medens Paulus med skriftrullen var symbolet på kirkens lære. I overenstemmelse med disse helgeners centrale position havde deres fester en omfattende og rig liturgi.

Et alter var inviet til Sct. Gertrud. Den populære abbedisse, der levede $\mathrm{i}$ det syvende århundrede, påkaldtes især af rejsende. 12 gårde udgjorde alterets økonomiske grundlag. Til et alter for den folkelige nødhjælper Sct. Erasmus el. Rasmus, der under de romerske kejsere Diokletian og Maximian overvandt usigelige pinsler, var der knyttet seks gårde. Sct. Rasmus kom sent til landet, og navnet blev almindelig kendt $\mathrm{i}$ anden halvdel af 15. århundrede. 
Endelig havde Sct. Jørgen eller Georg et alter i kirken. Ligesom Rasmus var han en af de 14 nødhjælpere, hvis bønner i særlig grad mentes at blive hørt. Muligvis har der været endnu flere sidealtre i den ældste sognekirke.

Sct. Nikolai kirke lå i nærheden af slottet og tingpladsen. Dens endegyldige forfald har været en kendsgerning i første halvdel af 16. århundrede. Som årsager nævnes tidens ugunst, men også de indre forhold f.eks. afladshandelen, der nåede et højdepunkt på denne tid og førte store summer ud af landet. I 1501 blev der på Gottorp slot sluttet en aftale mellem afladshandlerne og hertug Frederik. Den gik ud på, at alt, hvad der blev indsamlet, skulle nedlægges $i$ kister forsynet med tre låse og fores ud af landet for bl.a. at financiere kampen mod tyrkerne. Sønderborgs navn faldt dog sjældent i denne forbindelse. Byen var heller ikke p.g.a. mangelen på klostre direkte vidne til klostertugtens forfald. De store indre problemer i det kirkelige liv voldte alligevel besvær bl.a. i forbindelse med forholdene vedr. præsteembedets besættelse. For den gejstlige stands pengegriskhed og forargelige levned har de været ganske symptomatiske. Ydre politisk uro og kirkens indre problemer har tilsammen ført til den gamle sognekirkes forfald.

Det er ikke meget, der med sikkerhed kan siges om Sct. Nikolai kirke. Richard Haupt, der i tysk tid beklædte det vigtige embede som "Landeskonservator« for Slesvig-Holsten, har i 1908 udarbejdet et responsum i forbindelse med en påtænkt restaurering af Sct. Marie kirke. ${ }^{6}$ Han fastslog deri, at der ikke fandtes andre levn fra den ældste kirke end dele af et vievandskar, der blev opbevaret i museet på Sønderborg slot og muligvis et alter $i$ form af en gotisk skabstavle fra ca. 1450-1475 med malerifløje fra en noget senere tid identisk med alteret i Kegnæs kirke. Et af malerierne på dette alter viser biskoppen Sct. Nikolai. ${ }^{7}$ Endnu i første tredjedel af det 19. århundrede skal der have ligget ruiner på grundstykket, hvor den gamle kirke har stået. En port, der fører fra Batterivej til præstegården på Rosengade, kaldtes i folkemunde »æ kapitelsport « - formentlig et minde om Sct. Nikolai kirke.

Kirken omtales endvidere $\mathrm{i}$ procesakter fra det 16 . århundrede. Adelen bestræbte sig dengang på at købe fast ejendom i byerne, dels for at sikre sig et behageligt vinterophold, dels som kapitalanbringelse. Hertug Hans den Yngre og hertuginde Agnes Hedvig købte flere ejendomme i Sønderborg. I forbindelse med en af disse handler opstod der i 1594 en strid mellem Margarethe Sievertsen født Meinstorff, en dame af gammel slesvig-holstensk adel, og hertugen. Hun anklagede denne 


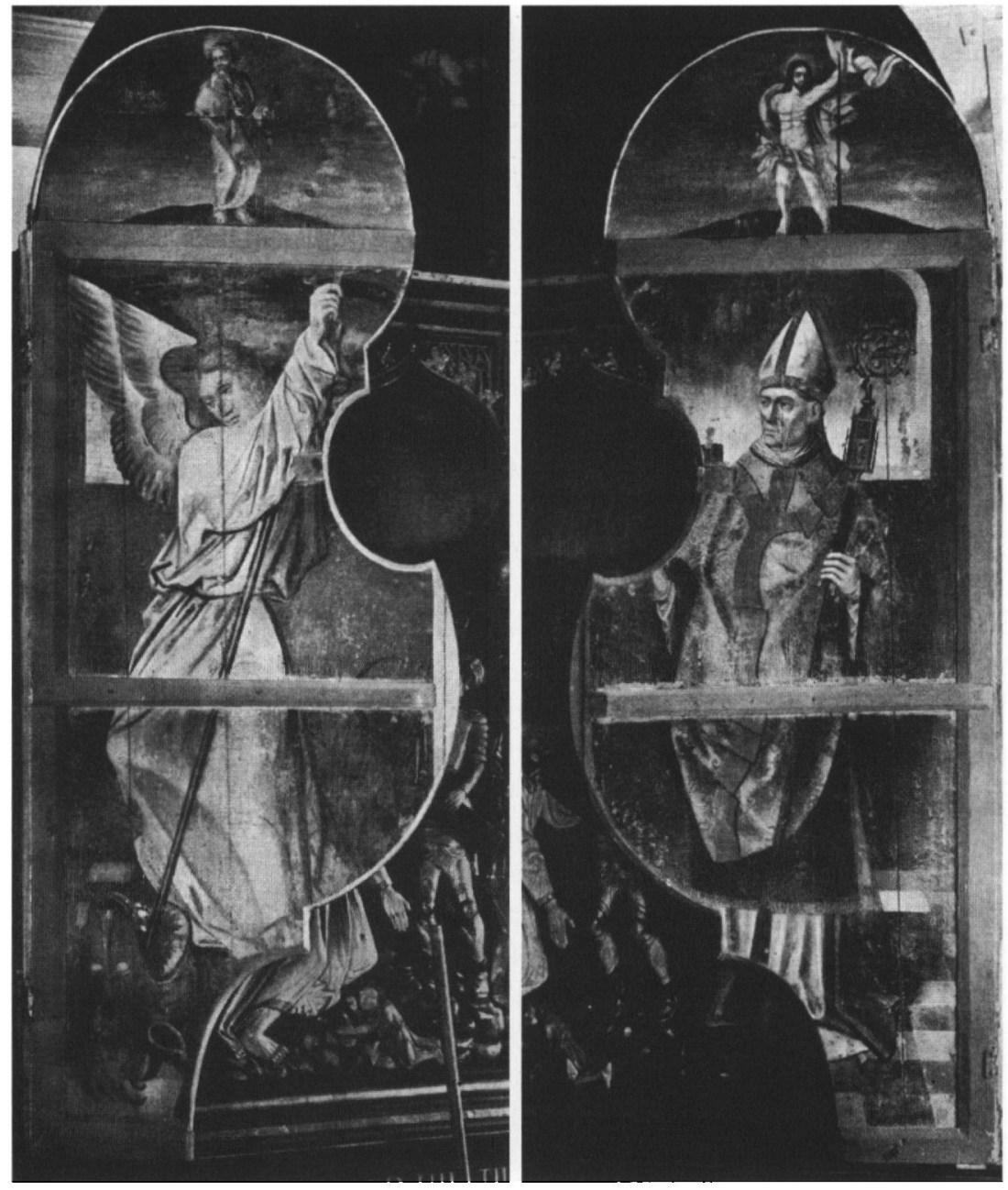

Altertavlen i Kegnæs kirke er muligvis taget fra Sønderborg kirke, hvor den kan have tjent som midlertidig alterprydelse til 1618, da denne kirke fik sin nye tavle. Kirken $i$ Sonderborg var indviet til Sct. Nicolai, som her ses på flejens malede bagside. Til venstre ærkeenglen Mikaels dragekamp. Gengivet efter Danmarks Kirker. Sønderborg amt s. 2391.

for at have tilegnet sig et hus, der retteligen tilhørte hende. Han havde taget det »med magt og revet det ned « for at bygge et nyt hus. ${ }^{8}$

Fru Sievertsen udtalte i denne forbindelse, at der "for adskillige, lange og næsten utænkelige år siden havde ligget en stiftskirke foran det fyrstelige hus og slot Sønderborg på bjerget«. Hertugens forfædre 
og andre adelige havde betænkt denne kirke bl.a. med 14 gårde på Als og i Sundeved. Som årsag til kirkens forfald nævnes i denne kilde de "højtbesværlige krigstider«.

Der kan i denne forbindelse tænkes på uroen omkring Christian II og Frederik den Is heldigt gennemførte bestræbelser på at tilkæmpe sig hertugdømmerne Slesvig og Holsten med magt. Efter kong Frederik Is død opstod den blodige krig kaldet "Grevens Fejde“, hvori Lybeks lejetropper bl.a. havde til hensigt at befri Christian II fra fangenskabet på Sønderborg slot. Følgen var, at slottet fik en stærk besætning af lejetropper og indkaldt mandskab fra Als og Sundeved. Den skulle i givet fald tage kongen i sikker forvaring og forsvare borgen til det yderste. Selvom de egentlige kampe kom til at foregå på Sjælland og i Nordjylland har forholdene i Sønderborg p.g.af Christian IIs fangenskab været præget af mangfoldige besværligheder og en del uro.

De omtalte gårde $\mathrm{i}$ kronens besiddelse havde Frederik I i 1529 for tro tjeneste overdraget en ridder ved navn Wolmar von der Herberge. Ridderen havde ligeledes fået det tidligere kalandhus, der lå ved siden af kirken. Huset hørte til fru Sievertsens arv, og havde givet anledning til retsstriden med hertugen. Om processens udgang foreligger der ingen oplysninger. Dette er så meget mere beklageligt, som kildens oplysninger forekommer at være troværdige.

Sønderborgs berømte "Keerkswarenbook ", kirkejuraternes protokol eller regnskabsbog, som omtales udførligt senere $i$ artiklen her, anfører i regnskabet for år 1600/1601, at den byggegrund, som Sct. Nikolai kirke havde ligget på, var blevet solgt til hertugen. Han var interesseret $\mathbf{i}$ grunden, fordi den lå op til hans have. Han betalte med "Vademhollte « d.v.s. Fadenholz (favnetræ), som blev fældet på Kegnæs og havde en værdi af 1001 Mark. $^{9}$

At byens ældste kirke var indviet til Sct. Nikolai kan ikke undre. Biskop Nikolaus fra det lilleasiatiske Myra var en af tidens mest kendte og populære helgener. Han har bl.a. beskyttet søfolk og andre, der var kommet i nød uden egen skyld. Sønderborg by og menighed med tæet tilknytning til havet har haft en naturlig interesse $i$ at vie sin sognekirke til denne helgen.

\section{Sct. Jørgens kirke og jomfru Maria}

I forbindelse med Sct. Nikolai nævnes som omtalt også den folkelige martyr-helgen Sct. Georg el. Sct. Jørgen. Den kappadokiske officer 
blev en af østkirkens helt store helgener. I Danmark opnåede han anerkendelse $i$ den sene middelalder og blev en af nødhjælperne. I løbet af 14. århundrede valgte samtlige danske spedalskhedshospitaler Sct. Jørgen til deres skytshelgen og kaldtes Sct. Jørgensgårde. Mange kapeller indviedes til ham, ligesom der opstod en særlig forbindelse mellem Sct. Jørgen og Jomfru Maria. Ifølge legenden er det hende, der sender ham i kamp med dragen.

Der kan dog ikke herske tvivl om, at Sct. Jørgens kapel eller kirke, der efter Sct. Nikolai kirkes forfald og nedbrydning mellem 1500 og 1541 blev byens anden sognekirke, har været indviet til Sct. Jørgen og ikke, som nogle har hævdet, til Jomfru Maria.

At kirken siden fik navn efter Jomfru Maria har en anden grund. Vi finder den i et dokument udstedt af væbneren Peter Stot (Petrus Stoed). Selvom der i teksten står "Datum anno domini MCCC in vigilia assumptionis Marie« er udstedelsesdatoen påskedag 1400. I dokumentet nævnes Johannes von Alckendorp som vikar ved kapellets Mariaalter. ${ }^{10}$

Ca. 100 år tidligere - i 1307 - havde en adelsdame i Esrom, John Litles datter ved navn Cecilie Sevi, skænket hospitalet i Sønderborg 7 mark. Dengang var dette en betydelig sum, som formodentlig har været medvirkende til, at den til hospitalet knyttede Sct. Jørgens kirke kunne opføres.

I 1550erne, da Christian IIIs dronning Dorothea havde fået Sønderborg som livgeding (underhold), tog hun sig også af hospitalet. Det blev omdannet til fattigstiftelse og alderdomshjem. Fundatsen af 1565 gengives sammen med forskellige oplysninger vedrørende hospitalet i en protokol og donationsbog fra 1587, der blev påbegyndt på foranledning af hertug Hans den Yngre. Institutionen havde et eget lille kapel i selve hospitalsbygningen, der i 1632 blev restaureret af hertuginde Dorothea - hertug Alexanders enke - og derefter modtog en del donationer $\mathrm{i}$ form af kirkeinventar m.v. Hertuginden havde sin egen stol $\mathrm{i}$ kapellet og kunne tre gange årligt overvære, hvordan der ifølge en ordning, som enkedronningen i 1571 havde truffet, blev prædiket for de 15 såkaldte "lemmer «, der boede $i$ institutionen. Hospitalet blev derefter iøvrigt hjemsøgt af forskellige plager. I 1639 døde 12 beboere af pest, og i $1658 \mathrm{blev}$ det under Svenskekrigene plyndret og ødelagt af de allierede dansk-brandenborgsk-polske tropper. Efter fuldstændigt at være berøvet sine midler og forsyninger blev der i den følgende tid skæn- 
ket væsentlige beløb til institutionen, der med tiden kom $\mathrm{i}$ besiddelse af en anselig formue. ${ }^{11}$

"Peter Støt von Sunderborg «, kaldes en "agtværdig og forstandig mand " af sønderjysk herremandsstand, og det var betydelige midler, som han sammen med sin hustru Katharina donerede vikariatet ved kirkens Maria-alter. Stiftelsen omfattede jordtilliggender i: Ulkebøl, Notmark, Sønderborg Mark, Ragebøl og Dybbøl, der kaldes Duttebull. Von Alckendorp måtte forpligte sig til at læse eller lade læse mindst fem messer ugentlig til minde om giverne og til ære for den Almægtige og Jomfru Maria.

Sammen med midler, som enkedronning Dorothea i 1571 har stillet til rådighed, menes Peter Støts stiftelse at have dannet grundlaget for Sct. Jørgens Hospitals anselige formue og for underholdet af byens latinske skolemester.

Der findes således i de nævnte dokumenter belæg for, hvorfor kirkens Maria-alter fik en fremtrædende placering i Sct. Jørgens kirke, hvilket iøvrigt var ganske $\mathrm{i}$ overenstemmelse med den åndelige udvikling i senmiddelalderen. Om kirkens øvrige altre erfarer vi intet. Jomfru Maria var størst af alle helgener, og dyrkelsen af hende tog $i$ den sene middelalder kontinuerligt til. Der var en tydelig tendens til at sidestille hende med Kristus, hvis forsonergerning hun fik andel $i$. Jo mere Kristus blev opfattet som den strenge dommer, desto stærkere blev billedet af Maria som barmhjertighedens moder, der altid gik i forbøn for menneskene. Hun blev senmiddelalderens mest søgte mellemled mellem Gud og mennesker. Kirker, kapeller og altre blev indviet til hende. I digtning, musik og den bildende kunst skabtes scener af hendes liv. Året rundt afholdtes Mariafester, og Ave Maria, bønnen som hvert fromt menneske bad tre gange til aftenklokkens klang, var mere populær end selveste Fadervor. Selvsagt blev utallige messer holdt til Vor Frues ære.

I disse forhold finder vi baggrunden for, at Sønderborgs tredje sognekirke af borgerne og den troende menighed fik tillagt Marias navn og århundreder senere også fik dette officielt tilkendt.

\section{Reformationstiden}

Maria-navnet overlevede Maria-alteret. Siden begyndelsen af det 17. århundrede hed byens sognekirke Sct. Marie kirke. Hvordan det er 
kommet til opførelsen af denne byens tredje sognekirke, foreligger der kun få informationer om.

Reformationen havde ændret det kirkelige liv. Tiden før det åndelige gennembrud havde været urolig. Christian II havde sat dagsordenen. Bl.a. Sct. Jørgens kirke havde dannet rammen om forhandlinger med afsendinge fra Lybek. Slottet var blevet belejret af hertug Frederik og måtte $\mathrm{i}$ april 1523 opgive efter hård kamp. Så fulgte tiden, hvor Christian II i 16 år sad som fange på slottet. Først efter den for landet sønderslidende krig ved navn "Grevens Fejde« fulgte afspændingen i 1544. Sønderborg tilfaldt Christian III på et tidspunkt, da reformationen allerede var kommet hertil.

Sammen med 23 andre gejstlige havde kongen i 1538 kaldt byens præst til Gottorp slot for at forhandle om en ny luthersk kirkeordning. Informationen tillader dog ikke at drage den slutning, at Sct. Jørgens kirkes præst på dette tidspunkt var evangelisk. Der blev så ved denne lejlighed af kongen udpeget fire »visitatorer", der skulle gøre tjeneste som evangeliske tilsynsmænd.

Forholdene på Als har iøvrigt været komplicerede. I middelalderen hørte øen sammen med bl.a. Ærø til Odense bispedømme. Efter enkedronning Dorotheas død i 1571 vendte også Sønderborg tilbage til Odense. Tilsynet skiftede dog atter. I modsætning til Als lå det fra den første evangeliske præsts udnævnelse frem til 1920 hos biskopperne i Slesvig.

Efter langvarige stridigheder mellem kongen og dennes bror, Hans den Yngre, fik hertugen i 1584 overraskende af kongen tilkendt kirkehøjheden over Sønderborgs kirker, d.v.s. Sct. Jørgens kirke og slotskapellet samt de kirker, som han fremtidigt måtte lade bygge. Mellem denne tildeling af kirkehøjheden og planerne om opførelse af en ny sognekirke $\mathrm{i}$ byen har der formodentlig været en forbindelse. Hertugen havde nu en personlig interesse $i$ at fremme sagen. Som luthersk fyrste havde han en principiel interesse i at synliggøre sin møjsommeligt tilkæmpede kirkehøjhed, som kongen udover de givne beskedne indrømmelser iøvrigt holdt fast ved.

Der er ligeledes grund til at hæfte sig ved en beretning fra 1585 , ifølge hvilken enkedronning Dorothea lod "gudshuset og hospitalet" gennemrestaurere. Men er der tale om Sct. Jørgens kirke eller om kapellet i selve hospitalsbygningen? Kunne der eventuelt være tale om forholdsregler, der blev truffet forud for den store ombygning af kirken? I 1585 havde den forlængst erstattet den forfaldne og nedbrudte 


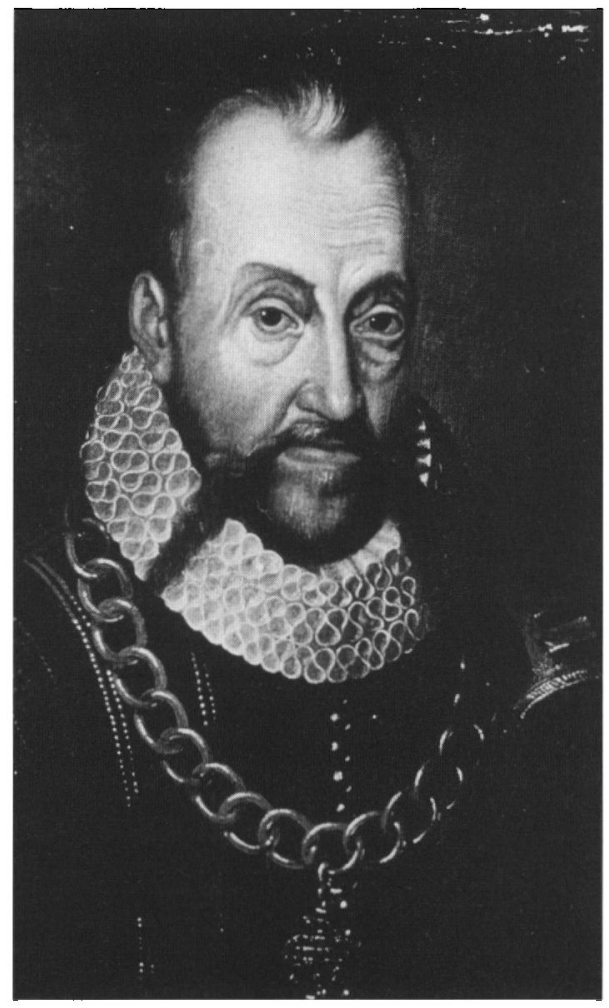

Hertug Hans den Yngre - 15711622 - var sammen med byens råd bygherre ved opforelsen af Sct. Marie kirke 1595-1600. Maleri på Frederiksborg museet fra ca. 1600.

Sct. Nikolai kirke som sognekirke, og menigheden skulle under alle omstændigheder fortsat have et sted, hvor dens gudstjenester kunne holdes.

Reformationen havde vundet sejr. I Landsarkivet opbevares et dokument, hvori Christian III kalder Johann Wechter til præst: "Inn unnse Stadt Sunderborch tho Sunte Jürgenn«. Sct. Jørgen var det officielle navn, der iøvrigt ofte skiftede. Sommetider kaldes kirken »bykirken « eller »kirken i Sønderborg «. Den nye præst skal forkynde "Euanngelionn Lutter, Reinn uund clar ...« d.v.s. i evangelisk ånd. Dokumentet blev udstedt i Aabenraa, søndag efter Hellig Trekonger 1541. Fra det tidspunkt har der med sikkerhed været ansat en præst ved kirken, der har været forpligtet på den evangelisk-lutherske lære. ${ }^{12}$

I første halvdel af 1550erne og slutningen af 1560erne var Olaus Christiani sognepræst i Sønderborg. I et dokument fra 1550, ligeledes underskrevet af Christian III, er der tale om: præsten, kaplanen og 
skolemesteren, der samtidig fungerede som kordegn. Kirken havde på det tidspunkt to præster og fik i 1617 den tredje. Fra 1570 til 1694 var der desuden knyttet en hofprædikant til Dorotheas kapel i slottet.

Reformationen kom ikke til Sønderborg sydfra, men fra bispesædet

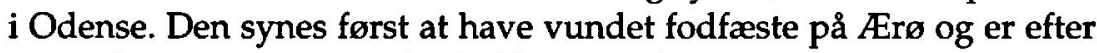
1530 nået til otte sogne på Als bl.a. Havnbjerg, Hørup, Ketting, Lysabild, Nordborg og Notmark.

\section{Sønderborgs "Keerkswarenbook"}

Visse antydninger i kilderne kunne tyde på, at forberedelserne til opførelsen af den såkaldte "nye kirke " påbegyndtes i 1584. Dette understøttes også af den på flere måder interessante regnskabsbog, "Keerkswarenbook «, der iøvrigt er det eneste pergamenthåndskrift, der findes i Landsarkivet i Aabenraa. ${ }^{13}$ Protokollen er påbegyndt i 1554, og den sidste afregning er dateret til den 4. februar 1733.

Keerkswarenbooken aflægger på 57 pergamentblade, indbundet $\mathrm{i}$ solidt brunt læder, regnskab over kirkens formueforhold. Derudover indeholder håndskriftet oplysninger om mange andre ting: fyrstelige donationer, menighedsmedlemmernes gaver, højtstående borgeres begravelse, anbringelse af kirkens ikke ubetydelige kapitaler, særlige kirkefester, præster, rådsmedlemmer og de borgere - og det forekommer at være næsten alle i byen - der havde opnået et lån, en såkaldt »hovedstol«, hos kirken til deres huse.

Amtmand Thomas Sture har udfærdiget regnskabsbogens indledende autorisation og borgmesteren, byens råd og især to kirkejurater, der senere blev reduceret til en, havde ansvaret for dens korrekte førelse. Kirkejuraterne var ansete borgere, som oftest medlemmer af byens råd. De var betroet med det særlige hverv at forvalte kirkens midler, sælge begravelsespladser inden og udenfor kirken, tage imod betaling for lån af brudekrans og for bryllups- og begravelsesringning m.v. Endvidere skulle de bogføre gaver til kirken og selvfølgelig alle udgifter.

Indtil 1623 blev regnskabsbogen ført på nedertysk, d.v.s. plattysk. Den samme hånd, der indtil slutningen af 1623 havde skrevet på nedertysk, fortsatte i 1624 på højtysk. Her fremgår kirkesprogets overgang fra neder- til højtysk klarere end noget andet sted. Til sammenligning kan anføres, at overgangen til højtysk kirkesprog i Aabenraa fandt sted betydeligt senere. Den første højtyske prædiken blev så- 
ledes holdt i 1659. Anledningen var en barnebegravelse, som blev foretaget af præsten Jørgen v. Hübschmann. Han noterede i kirkebogen: »Jeg har holdt ligprædikenen i det meissnerske sprog «. ${ }^{14}$

At det var højtysk, der blev det nye kirkesprog, kan kun begrundes teologisk. Det var et af Luther skabt enhedssprog, sammensat af det saksiske kancellisprog, som alle fyrster og konger i Tyskland fulgte, og folkesproget, som blev brugt ved oversættelsen af Bibelen, ved affattelsen af katekismerne m.v. Det var således anakronistisk, når tidligere tiders historieskrivning tillagde sprogskiftet i det 17. århundredes kirkeliv nationale motiver. Noget sådant kunne først komme på tale i begyndelsen af 19. århundrede, da den nationale tanke var opstået og efterhånden også blev bestemmende for kirkens dagsorden.

Deraf følger, at ejheller de tyske indskrifter på kirkeinventaret er blevet til af nationale grunde. Der er dels tale om indskrifter på nedertysk, der - som nævnt ovenfor - var kirkens sprog indtil begyndelsen af 1600-tallet, dels om den lutherske orthodoksis »hellige sprog «, højtysk, der blev indført af konkrete teologiske årsager, og bemærkelsesværdigt nok især blev fremmet af generalsuperintendenterne i hertugdømmernes kongelige dele, fremfor alt Stephan Klotz, der som kongens rådgiver prægede udviklingen i midten af 17. århundrede i mere end tre årtier. Som et kuriosum, der tydeligt klassificerer kirkens sprogbrug som et teologisk fænomen, kan der henvises til forholdene i Nykøbing Falster, hvor sognepræsten, magister Gregers Zimmer, prædikede højtysk i sin danske menighed. Kristian V så sig derfor $\mathrm{i}$ et brev af 27. februar 1692 nødsaget til at pålægge biskop Thomas Kingo: »at Du hannem derfor tilborligen reprimanderer ${ }^{15}$

\section{Sct. Marie kirkes opførelse}

I forbindelse med Sct. Marie kirkes bygningshistorie synes årstallet 1584 at have haft en hidtil overset betydning. Det kan ikke udelukkes, at visse hændelser i 1583 eller snarere 1582 har ført til særlig eftertanke og til øgede kirkelige aktiviteter. Afregningen pr. 11. februar 1584 nævner bytjenerne (Stadtdiener), der hver skulle have 1 Mark, fordi de i pesttiden havde udfort deres tjeneste på forbilledlig vis. En epidemi må altså kort forinden have hærget byen. Hjemsøgelsen skete i 1582. Sønderborg, der dengang var en by med ca. 2000 indbyggere, 
Renæssancegavlen pd Sct. Jørgens Hospital $i$ midten af 1880erne. Tegning af museumsinspektor Jens Raben 1963.

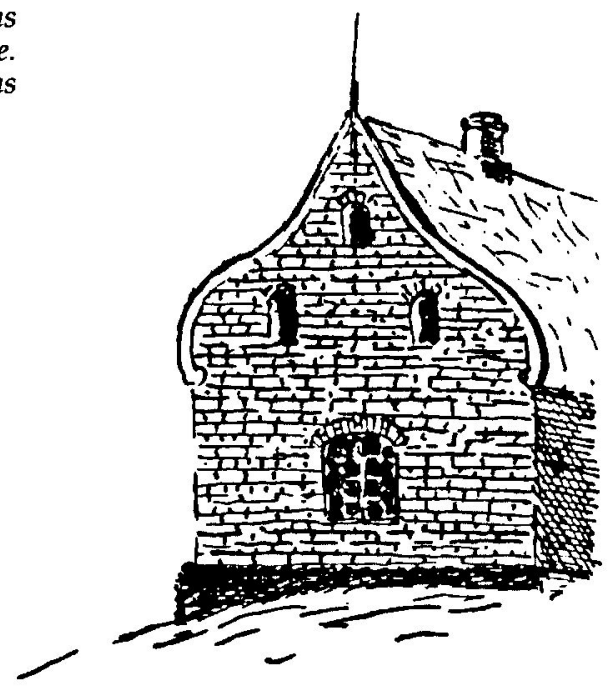

havde ved den lejlighed 300 dødsfald at beklage, hvilket udfra tidens opfattelse særdeles vel kunne have fremmet visse kirkelige tiltag.

Til de store udgiftsposter hørte i 1584 bl.a. en kirkerestaurering. I regnskabet taler kirkejuraterne gentagne gange om »der nien Kercken « - den nye kirke. En beretning om Sct. Jørgens Hospitalet fra 1585 indeholder ligeledes en oplysning om, at enkedronning Dorothea "dath nyd gottshus und Hospitall tho Sunderburg Sancti Georgius heff genomet, uth lauesamer mildicheit hefft upbuwen laten ....". ${ }^{16}$ Der er tale om en restaurering af Sct. Jørgens kirke, idet formuleringen "gudshuset og hospitalet « udelukker, at restaureringen gjaldt det lille kapel i selve hospitalsbygningen. Vi kan således antage, at der omkring 1584 er udført arbejder på Sct. Jørgens kirke. I forbindelse med aktiviteterne i 1584 blev der bl.a. nedbrudt flere huse sandsynligvis også kapellanen Jørgen Bruns bolig ved kirken. Udgifterne til dette arbejde beløb sig til 270 Mark lybsk, et anseligt beløb, som hertugen har hjulpet med at udrede. Det synes at være kirkejuraternes opfattelse, at den indledte ombygning skulle fortsætte, indtil en total renovering var gennemført.

Keerkswarenbookens oplysninger er dog vanskelige at gennemskue. De tillader imidlertid den forsigtige slutning, at man fra 1584 har planlagt og påbegyndt de bygningsmæssige aktiviteter, der førte til Sct. Marie kirkes indvielse ca. 16 år senere. 

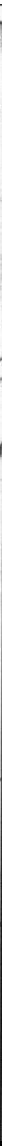

Kontrakten blev afsluttet mellem Hans den Yngre og byens råd på den ene og bygmester Peter de Castella på den anden side og er underskrevet den 24.3.1599 bla. af hertugen "Manu propriae». Landsarkivet Aabenraa.

Artiklen om Sct. Marie kirke i Nationalmuseets værk »Danmarks Kirker « omtaler ikke restaureringen i 1584. På grundlag af regnskabsbogens oplysninger om opkøb af en byggegrund med huse til nedrivning og diverse donationer til en ny kirke kommer den dog til det resultat, »at man i 1585 var i fuld gang med forberedelserne til en kirkeudvidelse .....17

Rigtig fart $\mathrm{i}$ byggeriet kom der først 10 år senere, idet der foreligger oplysninger om, at borgerne i Sønderborg i 1594 ved fastelavn begyndte at samle kampesten til fundamentet, og at de ved påsketid med understøttelse af hertugen har lagt dette. ${ }^{18}$ Murerarbejdet kom først i gang i 1595 .

Den tidligste byggefase omfattede koret, der stod færdig i 1597. For at kunne fortsætte de kirkelige aktiviteter, har man muligvis opført det nye kor udenom det ældre og først nedbrudt dette, efter at det nye har været færdig. Ydermurene har stået færdige i 1599. 
Koret blev på hertugens og byrådets forlangende et snarere middelalderligt virkende rum, hvis gavl dog har set noget anderledes ud, end den gør idag. Bygmesteren udformede den som en svungen renæssancegavl, der ved en senere lejlighed er blevet erstattet af den nuværende lige taglinie.

Keerkswarenbooken giver ingen nærmere oplysninger om byggeriet i slutningen af 1590erne. Bygherrernes forestillinger om kirkens dimensioner og arkitektoniske udformning kan man derimod få et indblik i ved at læse deres kontrakt med bygmesteren Peter de Castella. Der er tale om et velholdt dokument, der opbevares i Landsarkivet i Aabenraa.

Ifølge kontrakten, der den 24. marts 1599 blev underskrevet af hertugen med egen hånd (manu propriae), borgmesteren og 16 rådsmedlemmer og forsynet med bygmesterens eller "Murmeisterens" segl et våbenskjold med murske - og bogstaverne P. K., skal Peter de Castella nedbryde det gamle tag og korenden og derefter bygge kirken op »ud dem Orde, dar nu de olde gebuvet«, så den bliver dobbelt så stor som før, d.v.s. 22 favne lang, 18 favne bred og en favn højere end den gamle kirke. Koret skulle fornyes og de indre mål være $6 \times 5$ favne. Da det gamle danske længdemål favn svarer til 3 alen, d.v.s. ca. $1,9 \mathrm{~m}$, er den nye kirkes dimensioner ca. $41,4 \times 33,9 \mathrm{~m}$, korets er ca. $11,4 \times 9,5 \mathrm{~m}$, medens den nye højde på 4 favne svarer til ca. $7,6 \mathrm{~m}$. Også korhvælvingen skulle fornyes, og endelig skulle der til vestgavlen bygges et firkantet tårn, et »Torm vp dem. Westerende«, der ragede to favne op over kirkens tag.

Bygmesterens honorar for den »Nye Kerke«, der skulle opføres "Godt dem Allmechtigen to Ehren, vnd menniglichen dißer Stadt Sunderborch thom besten « androg 1320 Mark lybsk i rede penge og en læderdragt. Fra første til sidste arbejdsdag skulle de Castella underholdes af borgerskabet. Også murerarbejdsmændene, de såkaldte "plegeslüde«, skulle underholdes. Arbejdstiden fastlagdes på følgende vis: Arbejdet blev påbegyndt, når kirkeklokken slog fire om morgenen, og arbejdsmændene skulle om aftenen gå hjem på samme tid som murmændene. Der var således tale om en arbejdsdag af mindst 14 timer.

Der rejser sig mange spørgsmål i forbindelse med byggeriets gennemførelse og formelle tilrettelæggelse. Man var fire til fem år henne i processen, for der blev opstillet en kontrakt, hvori enkelthederne var nedfældet. Muligvis har man ved byggeriets start ikke an- 


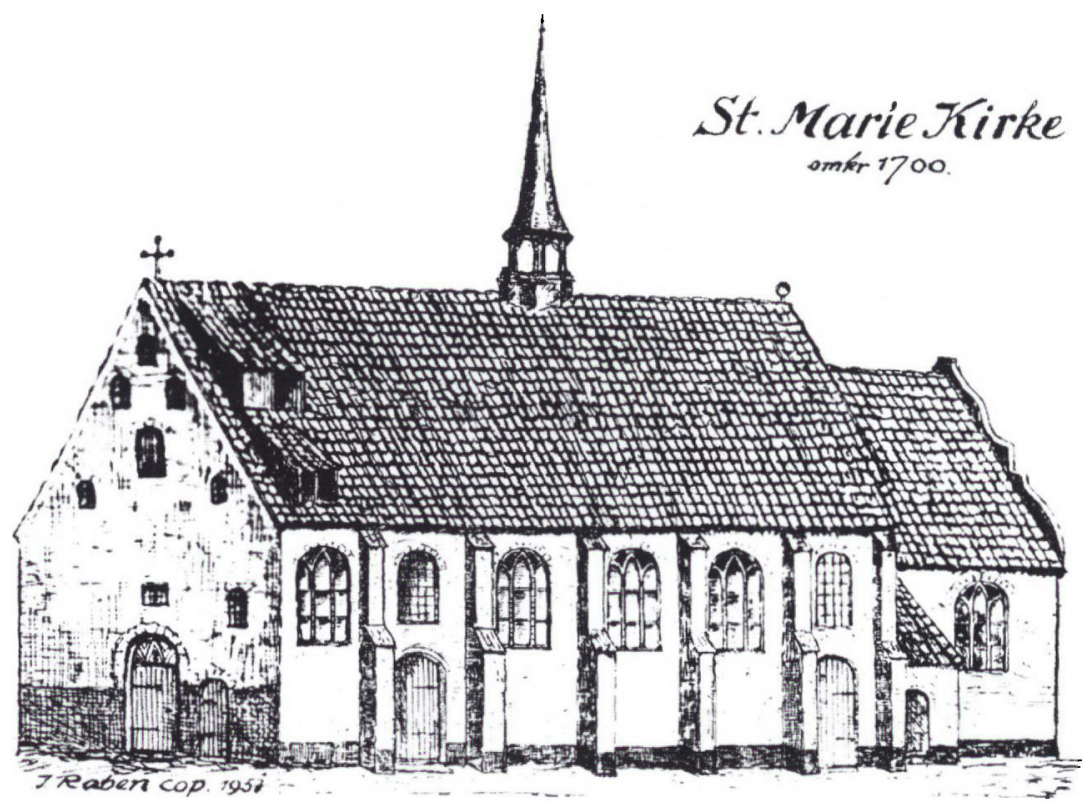

Sct. Marie kirke i drhundredet efter opførelsen. Det ydre: Kvadratisk kor, seksfags treskibet langhus, murværk af rode munkesten i renæssanceskifte, kampestenssokkel, dele af muroærket opført på den ældre kirkes sokkel. Det indre: Treskibet kirkehal med høje smalle sideskibe, koret bredere end midterskibet, kor, hovedskib og sideskibe dækket af ottedelte hvælvinger, vindeltrappe $i$ sydvesthjornet opfort 1600 som led $i$ planlagt tårnbyggeri. Tegning af museumsinspektør Jens Raben 1957.

set det for at være nodvendigt at formalisere tingene. Peter de Castella, hvis navn tyder på italiensk herkomst, var ikke nogen ukendt person $i$ byen. Hertugen kan have haft ham $i$ god erindring fra opførelsen af Glücksborg slot i årene 1582-1587. I 1590 var de Castella blevet borger i Sønderborg. Der er dog visse ting, der taler for, at han kom i økonomiske vanskeligheder og valgte at forlade byen uden at have gennemført kirkebyggeriet $i$ henhold til den indgåede kontrakt. I Keerkswarenbooken noteredes bl.a., at kirkejuraterne modtog 24 Mark fra en Kirstine Steffens, som denne skyldte de Castella. Under de givne omstændigheder tilfaldt de dog kirken.

Bygherrerne entrerede derefter den 11. april 1600 med »mester Jacob« for at få kirkebyggeriet afsluttet. Der foreligger ingen informationer om denne murermester. Regnskabsbogen tillader dog den slutning, at der må være tale om en mester fra regionen, muligvis fra Flensborg eller Glücksborg. Kirken har udbetalt ham godtgørel- 
se for en vandredag, hvilket var den tid, han brugte, for at nå til sit nye arbejde. I de følgende seks måneder har "mester Jacob « gennemført byggeriet med en arbejdsstyrke, der varierede fra 10 til 15 mand.

En præcis angivelse for afholdelse af den officielle kirkeindvielse findes ikke. Byggeriet var kort for jul år 1600 så langt fremme, at højtideligheden kunne gennemføres. Indvielsen blev foretaget af Hans den Yngres hofpræst, provst Peter Fabricius, der få år tidligere havde tiltrådt et præsteembede i Broager og i 1598 var blevet udnævnt til provst. Han stod på det tidspunkt endnu højt $i$ hertugens gunst og var en både rig og indflydelsesrig person.

Slutningen af hans embedstid blev derimod formorket af modgang og elendighed. Der var permanent uorden i hans regnskaber, og hustruen blev henrettet som heks, bl.a. fordi hun angiveligt skulle have forgivet degnen Knud Knudsen »så han blev et usundt menneske«. Han opnåede alligevel at efterfølge Fabricius, hvilket fik folk til at sige: "Af een klotte Foel kand blive en Hest, af Knud Degn er blefven en Præst«. Udnævnelsen var belønning for at have giftet sig med en af den glücksborgske fyrstindes kammerpiger. ${ }^{19}$

\section{Kirkens nygotiske tårn}

Der gik mange år før kirken blev helt færdig. Ret beset blev kirken i henhold til de oprindelige planer først færdigbygget i 1883. Før dette år opfyldte de svære piller $\mathrm{i}$ vestfaget og vindeltrappen i sydvesthjørnet ikke det formål, der var tiltænkt dem.

I 1881 besluttede menighedsrådet imidlertid, at kirken skulle have et tårn, og to år senere blev byggeriet sat igang. Enkeltheder vedrørende dets gennemførelse fremgår af et dokument, der blev fundet $i$ kuplen under den sidste restaurering i $1995 .^{20}$ Beskrivelsen skildrer, hvordan det $60 \mathrm{~m}$ høje tårn blev opført $i$ et aldeles hæsblæsende tempo. Tages tidens tekniske muligheder i betragtning, bliver præstationen endnu mere imponerende.

Arkitekt A.W. Prahle i Flensborg stod for projekteringen og har samtidig ledet og overvåget byggeriet, der blev gennemført af bygmester I. Prüss fra Gråsten.

Følgende informationer taler deres tydelige sprog:

Byggeriet blev påbegyndt den 6. juli 1883 .

Der kunne holdes rejsegilde den 8. september 1883 . 


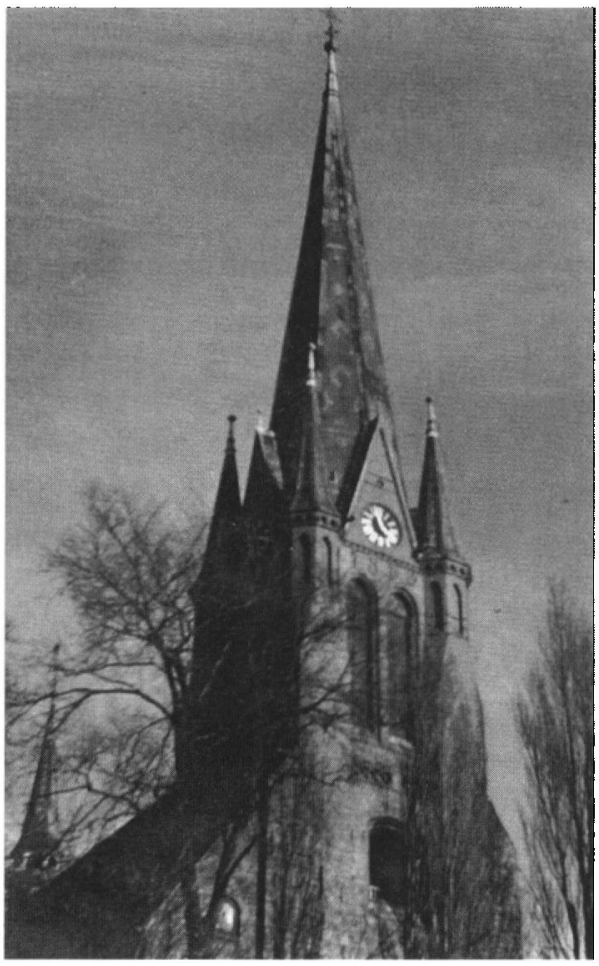

Kirketårnet af 1883 med et hovedog fire sidespir blev tegnet af arkitekt A.W. Prahle, Flensborg og opført af bygmester I. Prüss, Gràsten. Foto Heissel, Sønderborg før 1960.

Kuglen og korset anbragtes på tårnet den 10. oktober 1883 samtidig med, at de nye kirkeklokker og tårnuret blev installeret.

Indvielsen fandt sted på Martin Luthers 400 års fødselsdag den 10. november 1883.

Kirketårnet blev altså bygget på kun fire måneder, og det vel at mærke, uden at nogen kom til skade. En imponerende håndværksmæssig bedrift!

Landeskonservator Richard Haupt kritiserede det nygotiske tårn opført i tidens stil med ialt fem spir p.g.a. dets manglende sammenhæn med kirkens andre bygningsdele. Kritikken deltes af andre fagfolk, medens byens borgere ofte havde en anden opfattelse. Det vakte således en del postyr, da man i 1960-62 i forbindelse med den store restaurering, der blev gennemført ved arkitekt Helge Holm, København, fjernede de fire små hjørnespir og indkapslede de røde sten med nybrændte munkesten. Denne disposition forandrede tårnets hidtidige udseende og har - alt andet lige - givet helheden et tydeli- 
gere præg af renæssance. Bevidst eller ubevidst fulgte man ved at gå frem, som det var tilfældet, Richard Haupts intentioner.

\section{Kirkens indre liv}

Såvidt de ydre rammer. Men hvordan var da det kirkelige liv indrettet? I tiden umiddelbart efter opførelsen var der dansk froprædiken fra kl. 6-7. Højmessen, der indtil ca. $1625 \mathrm{blev}$ holdt på nedertysk og derefter på højtysk, blev indledt af salmesang fra kl. 7.30-8.30, hvorefter var der prædiken til kl. 9.30 og kirkebøn til kl. 10.

Tysk havde forstepladsen som gudstjenestesprog indtil 1850. På dette tidspunkt opnåede dansk og tysk ligestilling, samtidig med at gudstjenesterne blev delt ligeligt mellem præsterne. Hovedpræsteembedet skulle opslås med dansk forretningssprog, medens diakonen foreløbig skulle besørge de tyske gudstjenester.

Den prøjsiske magtovertagelse i 1864 hhv. 1867 bragte endnu et vendepunkt. Det blev nu atter overladt hovedpræsten at holde gudstjenesterne på tysk, medens diakonen skulle besørge de danske eftermiddagsgudstjenester. Det var desuden diakonens opgave hver fjerde søndag at prædike i kapellet i Sct. Jørgens Hospital opført efter Flensborg-arkitekten, professor P. Winstrups planer fra 1860 på hjørnet af Kirke Allé.

Efter 1920 blev der i forbindelse med den nye kirkelige mindretalsordning for de sønderjyske byer med bl.a. ligestillede sognepræster for de danske og tyske dele af menighederne indført en gudstjenestefordeling, der i det store og hele er identisk med den nuværende og har fungeret upåklageligt. I tiden for den nybyggede Christianskirkes indvielse i 1957 var der dansk højmesse i Sct. Marie kirke alle søndage med undtagelse af tredje søndag om måneden, hvor der var tysk højmesse i kirken og dansk i Menighedshusets eller Sct. Jørgens Hospitalets kirkesal. Den tyske del af menigheden havde endvidere højmesse den første søndag i måneden enten i Menighedshusets eller Sct. Jørgens Hospitalets kirkesal. De øvrige tyske gudstjenester foregik i Sct. Marie kirke som morgen- eller aftensang, ligesom der var dansk morgen- og aftensang i kirken de fleste søndage. Efter 1957 blev en af de tyske morgen- hhv. aftensange henlagt til Christianskirken.

Iøvrigt har kirkens indre liv ændret sig i takt med de skiftende kirkelige strømninger. Den lutherske ortodoksi afspejles bl.a. i de 61 bind, der opbevares $i$ kirkens gamle bogskab fra 1629 og af et par af 


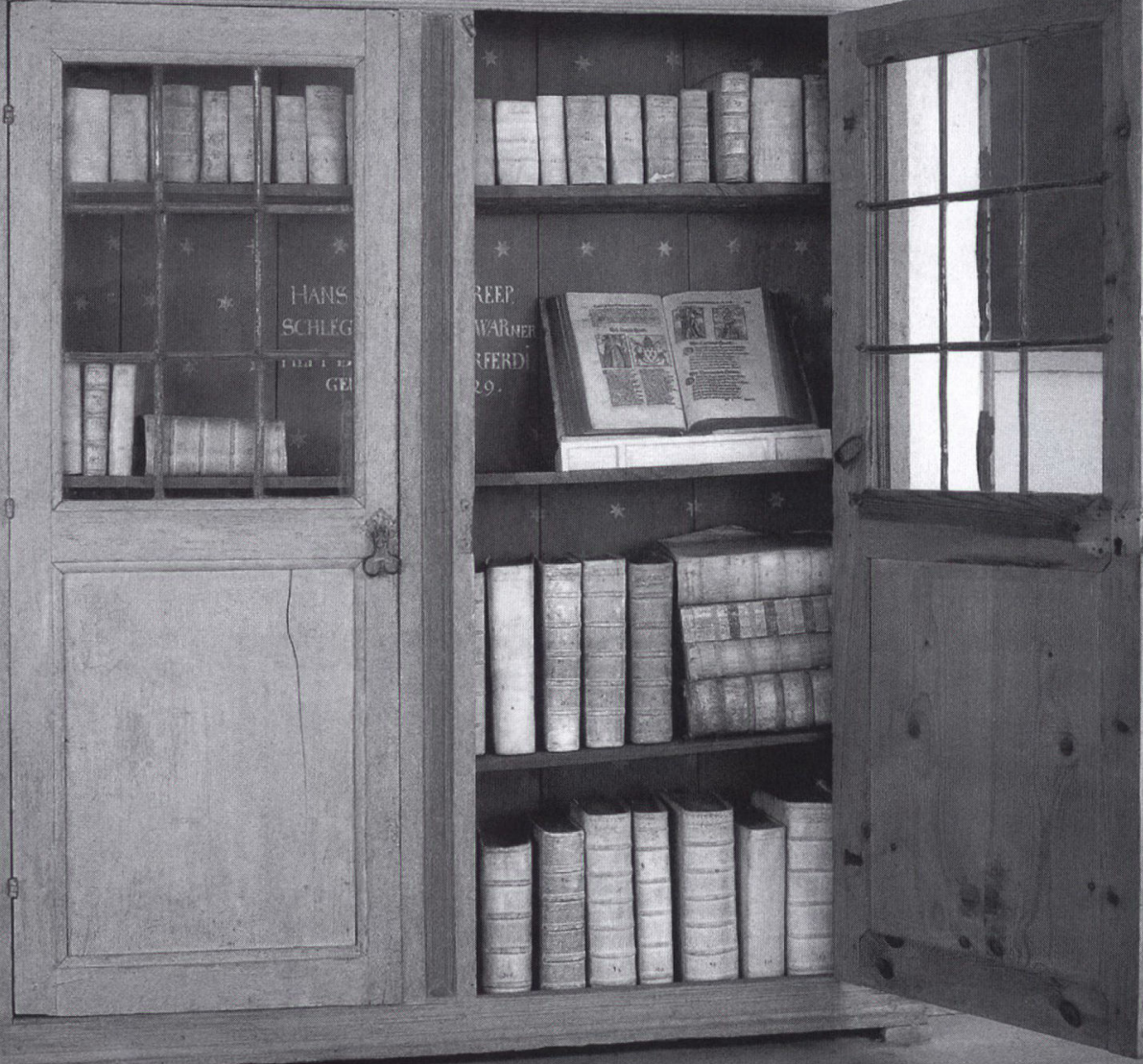

Sct. Marie kirkes bogskab findes i dag i Museet på Sonderborg Slot. Bogskabet er skænket til kirken 1. juni 1629 af kirkeværgen, rebslager Hans Lüdichsen. Skabet indeholder kirkens bogsamling pd $i$ alt 61 bind af hovedsageligt teologisk indhold. Den æeldste bog er trykt $i$ 1569, den yngste $i$ 1692. Foto Hans Arne Hansen, Museet på Sonderborg Slot.

de bevarede epitafier i kirken. Bogskabet og dets indhold kan ses på museet på Sønderborg slot. Værkerne er trykt i perioden 1569-1692 og bærer præg af periodens strenge kirketugt og stridbare dogmatiske ånd. ${ }^{21}$ De medlemmer af menigheden, der ikke søgte kirken og dens alter kunne ikke regne med at blive begravet $\mathrm{i}$ kirkegårdens indviede jord. Og havde en pige mistet sin mødom i utide, foregik bryllupet $\mathrm{i}$ skam, d.v.s. uden kirkens brudekrans. I 1661 påbød en forordning, at den offentlige kirkebod skulle holdes foran kirkedøren, hvor synderen knælende modtog tilgivelsen fra præstens hånd. På denne tid var 
kirkestolene formedelst et passende gebyr fordelt på familierne efter kald og stand, hvilket gav anledning til hyppige klager.

Fra 1617 blev der indført aftensang og hverdagsgudtjeneste om fredagen. Sct. Marie kirke havde nu tre præster: hovedpræsten, diakonen og vesperpræsten. En fjerde præst gjorde tjeneste ved slotskapellet.

Pietismen, der afløste den ortodokse periode, lagde vægten på »hjertets inderlige fromhed «, uden at den dogmatiske form iøvrigt blev ændret på gennemgribende vis. Det var holdningen til dans, kortspil, alkohol m.v. der i praksis blev kristenlivets målestok. I kirkens provst Balthasar Petersen (1739-1747) og byens borgmester (Frederik Gorressen 1740-1749), der samtidig var musikant, tørnede de to livsanskuelser i 1740erne heftigt og hørbart sammen, da provsten nægtede at træde dansen. På grund af det efterfølgende postyr faldt Sønderborgs provst $i$ en svær depression. Sønderborg omtaltes som en "syndens by" uden kirkegang, profaneret af søndagsarbejde, med spil og druk på helligdagene og plaget af en så total mangel på opdragelse, at børnene blev halvvilde. Pietisterne havde i alt det gode, de ikke mindst satte igang på pædagogikkens område, en tendens til at tegne et alt for sort billede af tilstandene i menigheden. På denne måde blev resultaterne af deres arbejde omså mere synlige. For første gang kunne man nu også møde konfirmander i kirken. Excesserne i byen ophørte og begravelserne blev gennemført uden tidligere tiders pragtudfoldelse, omfattende spiseorgier m.v.

Fra 1782 kaldte klokkerne til gudstjeneste en time senere end før, og der indførtes hverdagsgudstjeneste også om onsdagen ved ærkedegnen eller vesperpræsten, medens provsten stod for gudstjenesten om fredagen.

I midten af det 18. århundrede strømmede byens folk til kirke. Hovedpræsten blev på dette tidspunkt udnævnt af kongen, medens menigheden havde ret til at vælge diakonen blandt tre kandidater, der blev præsenteret af amtmanden.

I den efterfølgende periode satte rationalismen sit præg på Sønderborgs kirke- og menighedsliv. Følgen blev et drastisk fald i kirkebesøget og nadverdeltagelsen. I 1797 indførtes den berygtede Adlerske alterbog uden modstand fra menigheden, samtidig med at det private skriftemål ophørte. Generalsuperintendent Jacob Georg Christian Adler (1756-1834) havde fjernet alle de led og formuleringer i den hidtidige gudstjenesteliturgi, der ikke harmonerede med oplysningstidens 


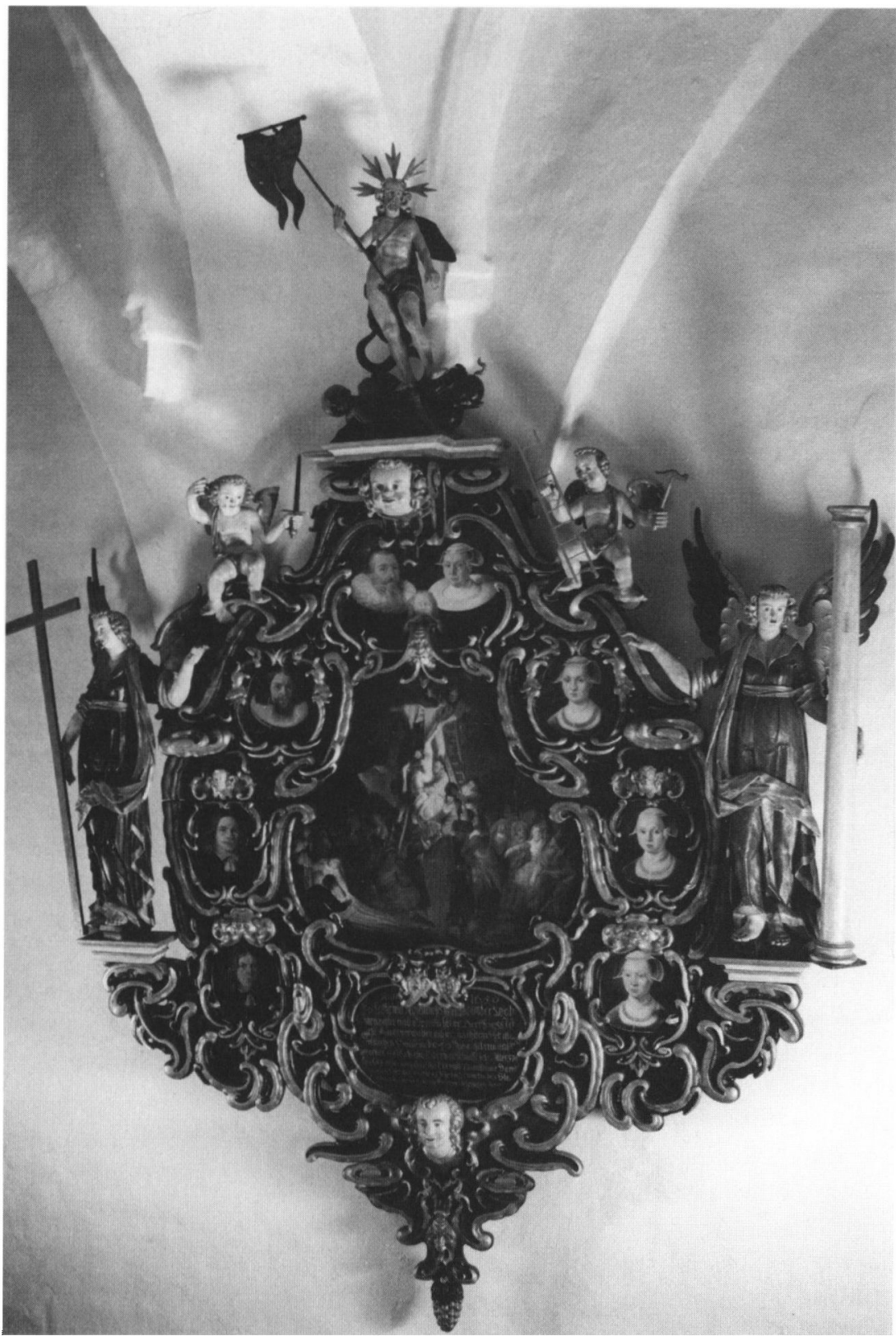

Epitafium i Sct. Marie kirke over amtsforvalter Hans Jebsen (1573-1650), sat af enken 1650. Storfeltets maler er Rembrandteleven Heinrich Jansen fra Flensborg. Foto Paul Willi Weber. 
smag og blege slagord: Gud, dyd, udødelighed. Fadervor, velsignelsen og meget andet, der ikke harmonerede med fornuften (ratio), blev tilpasset periodens forestillinger. Barnedåben skulle ikke foregå ved kirkens gamle døbefont, men i hjemmene, og nadveren blev kun fejret to gange årligt. I mange andre sogne udløste alterbogens indførelse eller planer derom heftige protester og demonstrationer med langvarige stridigheder til følge.

Da økonomien i begyndelsen af 1800-tallet var katastrofalt dårlig, blev det ene præsteembede nedlagt og søndagsgudstjenesterne reduceret til to. Der var endvidere en del debat om præsternes løn, der blev udredet af byens kasse. Diakonen måtte tage en lønnedsættelse til efterretning. Man ønskede samtidig at basere præstelønnen på diverse gebyrer for: skriftemål, dåb, barselkoners kirkegang, begravelse, hjemmealtergang, konfirmation m.v. Byens råd var af den mening, at præsterne med deres faste løn havde et »overflødigt og uafhængigt udkomme«, hvilket havde ligegyldighed overfor embedet til følge. De ansvarlige var derfor af den opfattelse, at det var bedre, at indtægterne rettede sig efter embedshandlingernes tal. Hovedpræsten protesterede dog højlydt, hvorefter alting forblev, som det var. Der skulle fortsat betales gebyrer for: trolovelse, giftermål, taksigelse fra prædikestolen, mindetaler og ligprædikener på prædikestolen.

Efterveerne fra denne $\mathrm{u}$-kristelige rationalistiske periode $\mathrm{i}$ kirkens liv blev først overvundet henimod slutningen af det 19. århundrede, samtidig med at menighedsrådet lod kirkens himmelstræbende nygotiske tårn opføre. Det nye vartegn indvarslede en opblomstring i menighedslivet, der kulminerede omkring århundredskiftet fra 19. til 20. århundrede. I begyndelsen af 20. århundrede blev menighedshuset "Bethesda« i Østergade bygget til værn mod tidens sekteriske strømninger som det første $i$ sin art i den slesvig-holstenske Landskirke. ${ }^{22}$

\section{Radikale forandringer efter 1920}

Folkeafstemningen og genforeningen i 1920 affødte den dybeste cæsur i den kirkelige udvikling i Sønderjylland i tiden efter den lutherske reformations indførelse. Med rette blev dette, uanset hvad man æstetisk måtte mene, i 1924 markeret ved, at Sct. Marie kirke fik sine forste og eneste danske inskriptioner på alterets nye vanger. Forslaget om at anbringe danske indskrifter med guld på sort grund i fløjfelterne på alteret $\mathrm{i}$ stedet for malerier, stammer fra Nationalmuseets 
inspektør Chr. Axel Jensen. ${ }^{23}$ De omfattende ændringer i de kendte forhold blev $\mathrm{i}$ disse år anledning til kontroversielle diskussioner.

Kirkerestaureringen i 1923-24 afspejler bl.a. en diskussion, som har bevaret sin aktualitet. En af debattens hovedaktører var museumsinspektør Jens Raben, der kendte forholdene omkring Sct. Marie kirke som få andre og bl.a. ledede udgravningerne af begravelserne under kirken. I sin kirkebeskrivelse fra 1957 lader han skinne igennem, hvad diskussionen har drejet sig om: "Ved restaureringen i $1924 \mathrm{blev}$ alteret forandret, to smalle udskårne vanger på siderne, med et lille postament med musikengle blev fjernet og erstattet med nye "vinger" med skriftsteder. Disse vinger og den moderne skrift passer på ingen måde til den smukke gotiske skrift under alterbilledet. Man ser, at der er noget nyt »lappet« til og det forskønner ikke alteret. Man burde ikke have pillet ved Niels Tagsens gode arbejde. De fjernede stykker fra alteret har forfatteren gemt på Museet på Sønderborg Slot, og måske kan man engang komme til den indsigt, at det vil være rigtigere at føre alteret tilbage til sin gamle skikkelse «. ${ }^{24}$

Jens Raben focuserede imidlertid ensidigt på de æstetiske aspekter og glemte, at de kirkehistoriske forandringer i 1920, som i kirken alene genspejles af de nye altervanger, har været de betydningsfuldeste siden reformationens indførelse. De æstetiske synspunkter kan i høj grad diskuteres. Ændringerne af 1924 synes i sammenligning med det tidligere alter at have skabt en mere velafbalanceret helhed af større bredde og tyngde. Og muligvis var det smalle alter med to små musikengle slet ikke Niels Tagsens oprindelige opstilling.

Indgrebet i Sct. Marie kirkes alter i forbindelse med kirkens 400-års jubilæum i 1999 må derimod udfra en kirkehistorisk betragtning anses for at være betænkeligt. Sognepræst Peter Grønlykke, Sønderborg, har præsenteret projektet $i$ »Haderslev Stiftsbog 2000 « $i$ form af en billedmeditation. ${ }^{25}$ De ikonografiske og æstetiske aspekter skal der i denne forbindelse ikke tages stilling til. Da menighedsrådet for Sct. Marie sogn har erhvervet retten til to billeder af Mette Ohlsen, Ertebjerg på Als, kaldet »Opstandelsen « og "Korsfæstelsen «, i »foreløbig to år«, skal der træffes en ny beslutning vedrørende anbringelsen af billederne, der af Grønlykke karakteriseres som »et moderne kunstnerisk udtryk for vor egen tid «. Artiklen omtaler imidlertid ikke, at forudsætningen for projektets genenemførelse har været fjernelsen af altervangerne fra 1924 med kirkens eneste danske indskrifter.

Nye kunstneriske former har selvsagt deres berettigelse som ud- 


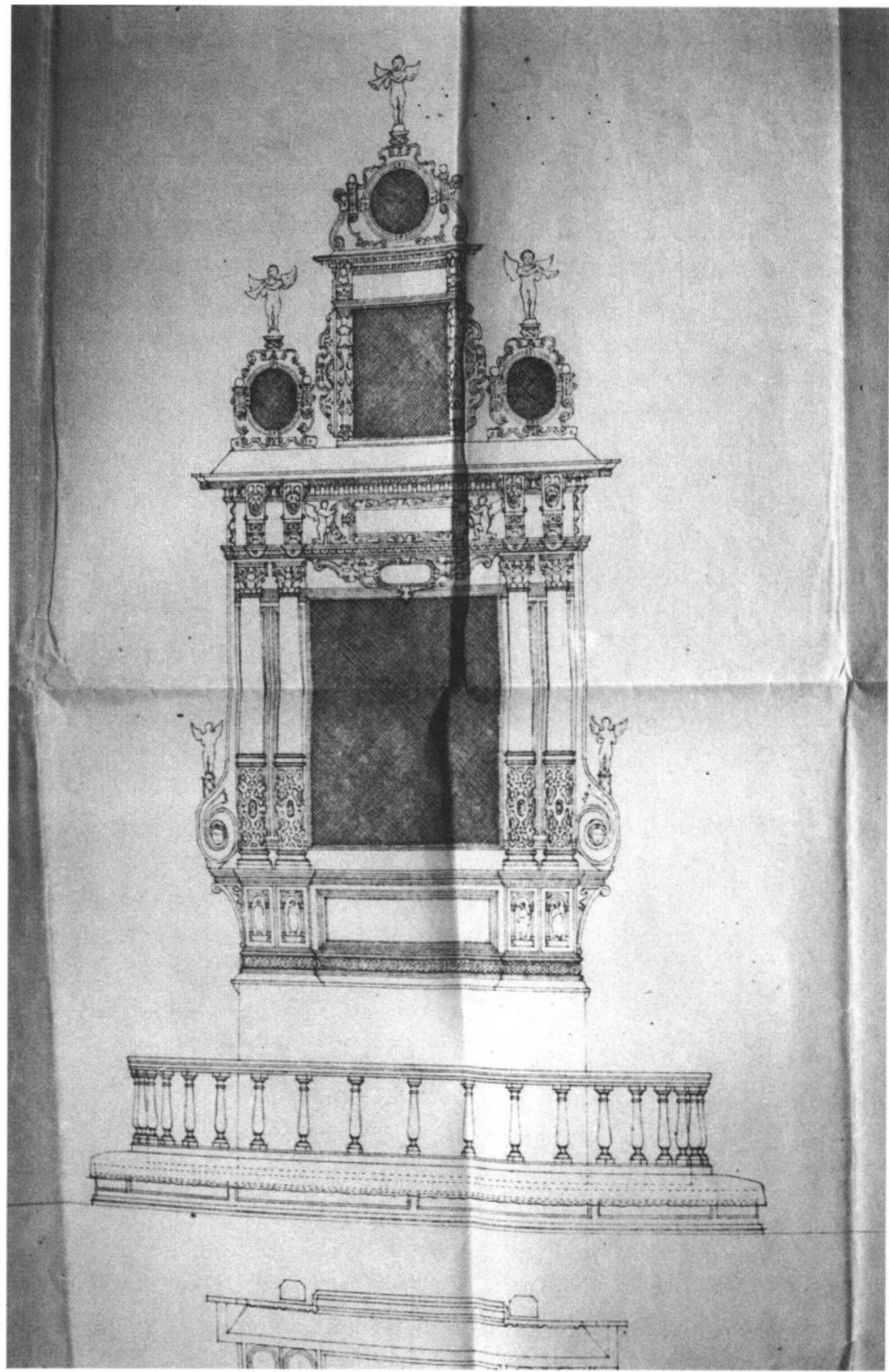

Sct. Marie kirkes altertavle, som den så ud for opsæiningen af de to tekstvinger med danske indskrifter $i$ 1924. Tegning af arkitekt Th. Havning, som forestod kirkens restaurering. Tegningen findes $i$ Marie kirkes arkiv i landsarkivet $i$ Aabenraa. 


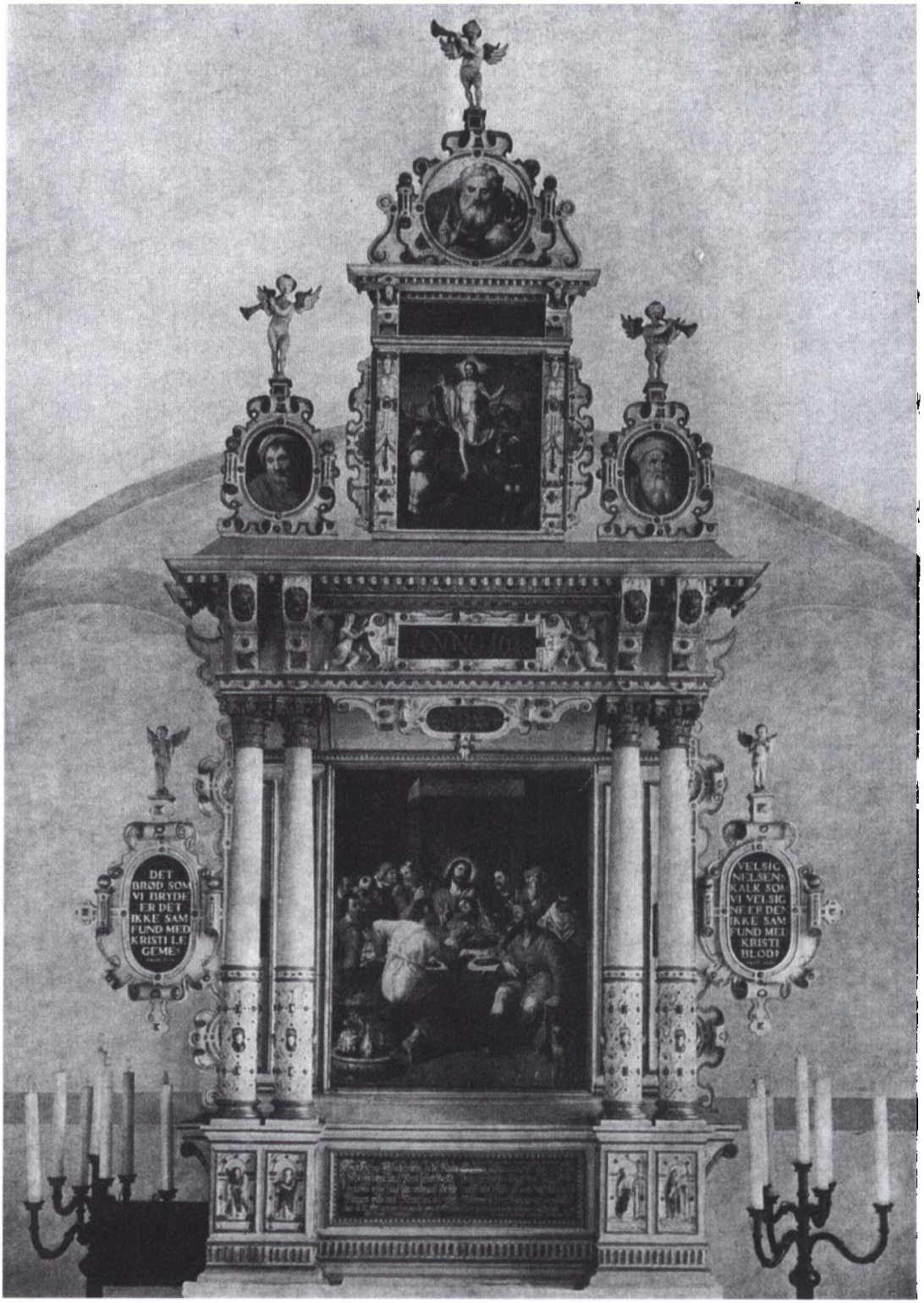

Alteret efter 1924 påmonteret vinger med danske indskrifter. Foto P.W. Weber, Senderborg. 
tryk for en stadig konfrontation med den historiske virkelighed. Fornyelsen bør dog ikke ske på bekostning af det kirkehistorisk unikke vidnesbyrd, som altervangerne udgør. Efter den lutherske reformation i 1500-tallet med sine radikale forandringer af kirkens ydre og indre forhold, er genforeningen i 1920 den historiske begivenhed, der har påvirket kirkelivet i Sønderjylland dybest og varigst. Den danske menighedsrådsordning repræsenterede kirkelige strukturer, der var vidt forskellige fra de hidtil kendte, der var fastlagt $i$ "Kirchengemeinde- und Synodalordnung für die evangelisch-lutherische Kirche der Provinz Schleswig-Holstein« af 1876. Endringerne på det liturgiske område med bl.a. en ny gudstjenesteordning, nye salmer, kirkedåb $\mathrm{i}$ stedet for hjemmedåb, hyppigere nadverdeltagelse m.v. var påfaldende. En ny præstetype flyttede ind i præstegårdene, og medlemmerne af folkekirken fik glæde af den danske kirkelige frihedslovgivning. Dansk fik som kirkesprog en central placering i kirkens liv, og i købstæderne indførtes en velfungerende kirkelig mindretalsordning. Slesvig bispedømme blev i den østlige del af Sønderjylland afløst af det pr. 30. juni 1922 nyoprettede Haderslev stift, medens Ribe i den vestlige del fik den nordlige del af Tønder provsti og Tørninglen provsti tilbage.

De nævnte eksempler kunne suppleres af betydeligt flere, og er udtryk for det markante brud i kirkelivet, der fulgte i den nye grænsedragnings kølvand. Sct. Marie kirkes altervanger med de danske indskrifter bør derfor bevares på deres oprindelige plads, fordi de synliggør dette tidehverv, der blev skelsættende for såvel den danske som tyske del af menigheden.

NOTER

1. Artiklen bygger på to foredrag, holdt den 26/10 2000 i Menighedshuset, Senderborg og den 19/11 2000 i Riddersalen på Sonderborg slot $i$ anledning af Sct. Marie kirkes 400 års jubilæum samt en udstilling om kirkens bygningshistorie konciperet for "Deutsches Museum Nordschleswig.".

2. Acta Pontificum Danica, bd. VI, s. 402.

3. Vedr. begrebet pavelig provisio jfr. Kulturhistorisk Leksikon for nordisk Middelalder, bd. 13, Kbh. 1981, spalte $533 \mathrm{ff}$.

4. Jfr. Dansk Præste- og Sognehistorie. Sonderjylland II, Haderslev stift. G. Weitling: Sonderborg Sct. Marie sogn s. 574. Henning Mathiesen, Senderborg skyldes tak for vigtige henvisninger om Henrik Holck.

5. Jfr. Trap Danmark 5. udg., Kbh. 1967. 
Aabenraa-Senderborg amt, bd. X, 3, s. 1223 ff. og Jens Raben: Ein Beitrag zur Adelsgeschichte des Kreises Sonderburg $\mathbf{i}$ "Heimat-Blätter für den Kreis Sonderburg « 1919/3, s. 34 ff.

6. Richard Haupts responsum - "Die Kirche zu Sonderburg “ - er trykt i "Heimat-Blätter für den Kreis Sonderburg « hæfte 5/1923 s. 21-27.

7. Jfr. Danmarks Kirker XXIII, s. 2384 ff.

8. På grundlag af akter fra det daværende "Staatsarchiv Schleswig " (Act. A. XIX nr. 292) skrev $H$. Wullenweber artiklen: Über die ehemalige St. Nikolai-Kirche in Sonderburg. "HeimatBlätter für den Kreis Sonderburg " $1920 / 4$, s. 50 ff.

9. Sammesteds, s. 52 .

10. Landsarkivet Aabenraa (LA $\AA$ ) Senderborg præstearkiv H 16, 1541-1618 og uden dato, Div. ældre sager. "Johannes de Alkendorp, perpetuus vicarius altare beate virginis Marie in capella Santti Georgii in Sunderburgh«.

11. Jfr. Jens Raben: Zur Geschichte des St. Jürgens-Hospitals in Sonderburg. "Heimat-Blätter aus Nordschleswig", Aabenraa 1943, s. 216 ff. Jfr. også: Per Fog (red.) De borgerlige klostre i Danmark, Aalborg 1990, s. 53 ff. (Sct. Jorgens Hospital i Sønderborg).

12. LAÅ Sønderborg præstearkiv H 16, andetsteds, Div. ældre sager.

13. LAÅ Sønderborg præstearkiv Ca 1 1554-1733 Kirkeregnskabsbog.

14. "Ick hebbe de lyckpredigt ... geholten in der Meißnischen Sprache". Citeret af Thomas Otto Achelis $i$ "Die großen Kriege des siebzehnten Jahrhunderts im Lichte nordschleswigscher Kirchenbücher 2. Teil: 1657-1659«. Deut- scher Volkskalender Nordschleswig 1934, s. 55 f.

15. Erik Pontoppidan: Det Danske Sprogs Skiæbne Udi Sonderjylland eller Førstendømmet Slesvig. Genudgivet af Grænseforeningen ved Gudmund Schütte, København 1943, s. 31, note 32.

16. Gengivet hos Jens Raben: Das Kloster St. Jürgen in Sonderburg. "HeimatBlätter aus Nordschleswig“, Aabenraa 1936, s. $38 \mathrm{f}$.

17. "Danmarks Kirker« bd. XXIII, s. 2063.

18. Jfr. Neues Staatsbürgerliches Magazin udg. af N. Falck, X, Schleswig 1841, s. 565 f. Jfr. "Danmarks Kirker« bd. XXIII, s. 2063.

19. Dansk Præste- og Sognehistorie, andetsteds, s. 635.

20. Dokumentet med mange informationer om byggeriet og informationer om byens og kirkens forhold blev den 1/12 1995 læst og oversat af forf. for Sct. Marie sogns menighedsråd i Sonderborg. Kapslen med dokumentet blev sammen med kuglen og korset indviet af sognepræst Peter Hinrichsen Godt (1877-93) under tilstedeværelse af kirkekollegiet, tilloddet, lagt $i$ kuglen og fastgjort på tårnets spids.

21. Titlerne er opført i "Danmarks Kirker«, andetsteds, s. 2095-2098.

22. LAÅ Senderborg Præstearkiv H 7, 1903-1917 Menighedshus.

23. LAÅ Sonderborg præstearkiv H 5 , 1923-1924 Restaurering.

24. Jens Raben: St. Marie Kirken i Sønderborg. Fra Als og Sundeved, hefte XXXVI, Sonderborg 1957, s. 19.

25. Peter Grønlykke: To billeder i Sct. Marie Kirke, Sønderborg. i "Haderslev Stiftsbog 2000«, Haderslev, s. 81-85. 